\title{
Evaluation of sulfamethazine removal kinetics using fixed structured bed bioreactor
}

\section{Guilherme Flandoli Romeiro, Cristiane Arruda Oliveira, Inês N. Tomita,} Álvaro J. Santos-Neto, Marcelo Zaiat \& Paulo Clairmont F. Lima Gomes

To cite this article: Guilherme Flandoli Romeiro, Cristiane Arruda Oliveira, Inês N. Tomita, Álvaro J. Santos-Neto, Marcelo Zaiat \& Paulo Clairmont F. Lima Gomes (2019) Evaluation of sulfamethazine removal kinetics using fixed structured bed bioreactor, Environmental Technology, 40:8, 979-987, DOI: 10.1080/09593330.2017.1414315

To link to this article: https://doi.org/10.1080/09593330.2017.1414315

Accepted author version posted online: 06

Dec 2017.

Published online: 04 Jan 2018.

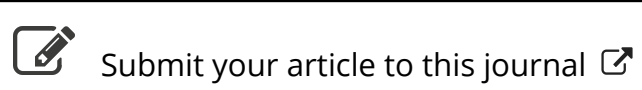

Џلll Article views: 116

View Crossmark data ¿

Citing articles: 1 View citing articles $\longleftarrow$ 


\title{
Evaluation of sulfamethazine removal kinetics using fixed structured bed bioreactor
}

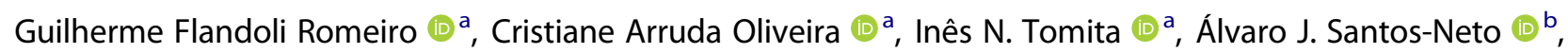 \\ Marcelo Zaiat (10 ${ }^{a}$ and Paulo Clairmont F. Lima Gomes (10 ${ }^{c}$

\begin{abstract}
${ }^{a}$ Biological Processes Laboratory, Center for Research, Development and Innovation in Environmental Engineering, São Carlos School of Engineering (EESC), University of São Paulo (USP), Environmental Engineering - Bloco 4-F, São Carlos, SP, Brazil; 'bnstitute of Chemistry of São Carlos, University of São Paulo, São Carlos, SP, Brazil; 'Institute of Chemistry, Department of Analytical Chemistry, São Paulo State University (UNESP), Araraquara, SP, Brazil
\end{abstract}

\section{ABSTRACT}

The use of anaerobic biomass attached to a support has been recently presented as a good prospect in the treatment of wastewater containing recalcitrant compounds, such as sulfamethazine (SMZ). SMZ has been found in swine wastewater and sewage treatment plants, which motivates assessing their degradation by new wastewater treatment technologies. Thus, this paper describes the use of a continuous fixed structured bed bioreactor for the purpose of evaluating SMZ removal kinetics present in lab-made wastewater. The analysis of SMZ used online solid-phase extraction coupled to liquid chromatography/tandem mass spectrometry (SPE online-LC-MS/MS). Chemical oxygen demand (COD) was also monitored to evaluate the organic matter removal. The bioreactor was operated under mesophilic conditions $\left(30^{\circ} \mathrm{C}\right)$, with a hydraulic retention time of $24 \mathrm{~h}$. In order to evaluate SMZ removal, four different concentration levels were studied: $200,400,600$, and $800 \mathrm{ng} \mathrm{L}^{-1}$. COD removal efficiency obtained for filtered effluent kept at $91.01 \%$ and there was no interference due to the increase of SMZ concentration. For SMZ, the removal efficiencies were of $52.8 \pm 12.1 \%$ for $200 \mathrm{ng} \mathrm{L}^{-1}$ concentration level; $55.0 \pm 8.15 \%$ for $400 \mathrm{ng} \mathrm{L}^{-1} ; 53.0 \pm 6.14 \%$ for $600 \mathrm{ng} \mathrm{L}^{-1}$, and $48.8 \pm 5.44 \%$ for $800 \mathrm{ng} \mathrm{L}^{-1}$. COD removal kinetics presented a first-order apparent removal rate constant $\left(k^{\text {app }}\right)$ of $0.281 \pm 0.0295 \mathrm{~h}^{-1}$. SMZ also showed a first-order apparent removal rate constant of $0.158 \pm 0.0093 \mathrm{~h}^{-1}$ for the following concentrations levels: $200,400,600$, and $800 \mathrm{ng} \mathrm{L^{-1 }}$.
ARTICLE HISTORY Received 20 July 2017 Accepted 29 November 2017

KEYWORDS

Bioreactor; wastewater; sulfamethazine; LC-MS/MS; removal kinetic

\section{Introduction}

Antibiotics are an important category of pharmaceuticals commonly used in human or veterinary medicine $[1,2]$. According to Gracia-Lor et al. [3], depending on the compound nature, up to $95 \%$ of the administered dose is excreted in urine and feces in its non-transformed form (NT). Potential sources for the occurrence of pharmaceuticals in the environment derive from: waste generated by the pharmaceutical industry and pharmacies, hospital waste, excretion of medicines applied in livestock, and agricultural use of biosolids as organic fertilizers through leaching that can reach groundwater $[4,5]$.

Sulfamethazine (SMZ) is an antimicrobial member of the sulfonamide class [6]. Owing to its high use, this antimicrobial has been found in receiving bodies of wastewater [7-9]. According to Focazzio et al. [10], in the United States SMZ concentrations are found in WWTP effluents at a mean concentration of $360 \mathrm{ng} \mathrm{L}^{-1}$.
Figure 1 shows the chemical structure of $S M Z$, an antimicrobial widely used as a growth promoter in farming and as treatment and prevention of infections, such as urinary tract infections, rheumatic fever, toxoplasmosis, and other diseases [12].

Studies have been conducted for genotoxic and ecotoxicological effects on flora and fauna [13]. The increased use of antimicrobials over the last five decades may have resulted in a genetic selection of resistant bacteria, with chronic effects that remain unknown, resulting in the need for new research on the removal evaluation of antimicrobials in WWTP $[14,15]$. Moreover, the United Kingdom Department of Health (UK) published a Review on Antimicrobial Resistance (AMR) 2016, in which it is pointed out that 10 million patients will die by infections caused by microorganisms resistant to antibiotics in 2050 . Nowadays, about 700,000 patients die from AMR infections [16]. Poor sanitation condition is an important cause of AMR infections.

CONTACT Paulo Clairmont F. Lima Gomes pauloclair@iq.unesp.br $\mathrm{B}$ Institute of Chemistry, Department of Analytical Chemistry, São Paulo State University (UNESP), 14800-060, P.O. Box 355, Araraquara, SP, Brazil

(c) 2018 Informa UK Limited, trading as Taylor \& Francis Group 
<smiles>Cc1cc(C)nc(NS(=O)(=O)c2ccc(N)cc2)n1</smiles>

Figure 1. SMZ chemical structure adapted from [11].

The Brazilian Institute of Geography and Statistics published in 2010 an official statistical survey related to Brazilian sanitation conditions. Only $55 \%$ of households presented sewage collection, and about $27 \%$ of this sewage is treated [17].

The detection of antimicrobials in receiving water bodies from WWTP effluents indicates the inefficiency of current wastewater treatment processes for the removal of these recalcitrant compounds, which are found at low concentrations (ng L ${ }^{-1}$ to $\mathrm{Mg} \mathrm{L}^{-1}$ ) [1821]. Based on this fact, alternative improvements are crucial to overcome this issue in order to effectively remove pharmaceutical compounds such as SMZ. Anaerobic bioreactor is widely applied and a versatile treatment technology, since it presents a low energetic demand and produces less excess of sludge compared to aerobic reactors. Furthermore, wastewater with high chemical oxygen demand (COD) or even with low COD could be treated by anaerobic bioreactors only requiring an acclimation period. This technology is suitable to tropical climate regions, requires a small area, and generates an energy source such as methane following the biorefinery concept $[22,23]$. Anaerobic technology can eventually require post-treatment processes and removal efficiency varies significantly with bioreactors operation parameters such as $\mathrm{pH}$, temperature, and hydraulic retention time (HRT).

This study aims to evaluate SMZ removal efficiency found at a concentration level of $n g \mathrm{~L}^{-1}$ by a fixed structured bed bioreactor (ABFSB). This anaerobic reactor favors the growth of a microbial community retained in the foams strips used as support which avoids accumulation of solids in the bed, avoiding undesirable effects such as channeling and clogging. The use of foam strips permits biomass acclimation and optimal condition for the removal of recalcitrant compounds, such as antimicrobials [24]. The ABFSB has been used successfully by [25] in the removal of $\mathrm{Cd}^{2+}$ and $\mathrm{Cu}^{2+}$ from wastewater. ABFSB reactor configuration was successfully applied for removal of sulfate present in lab-made sewage [26].

\section{Materials and methods}

\subsection{Reactor}

The acrylic bench-scale ABFSB was used to evaluate COD and SMZ removal. The ABFSB was planned as described in [25] using a working volume of $2.5 \mathrm{~L}$. The reactor was filled with polyurethane foam (16 fixed foam strips, 190 $\mathrm{cm}^{3}$ volume, $23 \mathrm{~kg} \mathrm{~m}^{3}$ apparent density, and $95 \%$ porosity), obtaining $190 \mathrm{~mL}$ of working volume. The inoculum was collected from a bioreactor used for the treatment of slaughterhouse wastewater. The inoculum immobilization in the polyurethane foam procedure was carried out as described by Zaiat et al. [27].

Sampling ports were inserted in the lower and the upper part of the reactor for sample collection. There were also three intermediate collection points. The distance between the sampling ports was $10.0 \mathrm{~cm}$ and the ABFSB height was $60.0 \mathrm{~cm}$, consisting of $6.50 \mathrm{~cm}$ of headspace.

\subsection{Reactor operation}

The ABFSB was operated at $30^{\circ} \mathrm{C}$ and total HRT of $24 \mathrm{~h}$ during 262 days. A lab-made sewage was used as a reactor substrate with a COD of $550 \mathrm{mg} \mathrm{O}_{2} \mathrm{~L}^{-1}$ as described in Table 1. SMZ was spiked in the lab-made sewage after the ABFSB achieved the steady-state regime. Four different $S M Z$ concentrations were studied: 200, 400, 600, and $800 \mathrm{ng} \mathrm{L}^{-1}$. Influent (lab-made sewage) and reactor effluent analyses were carried out using LC-MS/MS. SMZ is reported in the WWTP effluent at a mean concentration of $360 \mathrm{ng} \mathrm{L}^{-1}[10,28]$. Based on this value, concentration levels were selected to evaluate $S M Z$ removal efficiency. SMZ removal kinetics was

Table 1. Lab-made sewage composition adapted from [25].

\begin{tabular}{lc}
\hline Component & Concentration $\left(\mathrm{mg} \mathrm{L}^{-1}\right)$ \\
\hline Sucrose & 47.8 \\
Starch & 148 \\
Cellulose & 47.2 \\
Meat extract & 215 \\
Soybean oil & 51.0 \\
$\mathrm{NaHCO}_{3}$ & 728 \\
$\mathrm{KH}_{2} \mathrm{PO}_{4}$ & 120 \\
$\mathrm{NaCl}$ & 250 \\
$\mathrm{CaCl}_{2}$ & 7.00 \\
$\mathrm{MgCl}_{2}$ & 4.50 \\
Surfactant & 15.0
\end{tabular}


assessed by a spatial profile collected in the ABFSB. COD removal kinetics was also evaluated.

\subsection{LC-MS/MS analysis}

A liquid chromatography/tandem mass spectrometry (LC-MS/MS) developed and validated method was applied to determine SMZ in the reactor influent and effluent. As the SMZ is polar and soluble in water, LCMS/MS is the technique of choice for its analysis due to the ability to separate and quantify this kind of compounds with high detection capacity, selectivity, and efficiency [29-31].

The SMZ removal was analyzed using online solidphase extraction coupled with liquid chromatography by a column switching technique (SPE online-LC-MS/ MS). This method followed the same procedure of a previous method developed by Lima Gomes et al. [32]. The method involves a simple sample preparation procedure, samples' $\mathrm{pH}$ was adjusted to 3.0 with formic acid $0.1 \%$ solution followed by two filtrations using two different membranes (pore size: 0.70 and $0.22 \mu \mathrm{m}$ ). The samples were then injected into the SPE online-LC-MS/MS system. Approximately $5 \mathrm{~mL}$ of samples were collected to perform this analysis. After $\mathrm{pH}$ adjustment and filtration, the samples were stored in $15 \mathrm{~mL}$ falcon tubes and refrigerated for 1 week until being analyzed.

The SPE online-LC-MS/MS method was validated according to international guidelines [33,34]. Quantification limit (LOQ), linearity, precision intra- and interday, and stability parameters were assessed following the same criteria of Lima Gomes' [32] method. LOQ was determined as signal-to-noise ratio of 10 , it was also the first calibration level $\left(100 \mathrm{ng} \mathrm{L}^{-1}\right)$. Three different concentration levels in triplicate were assessed for intraand inter-day precision.

\subsection{Reagents}

Purified water was produced in the laboratory by a Milli-Q Plus Ultra (Billerica, MA) purification system. All pharmaceutical standards used were of high-purity grade $(\geq 98 \%)$.

Sulfamethazine (SMZ) and ${ }^{13} \mathrm{C}-\mathrm{SMZ}$ were obtained from Sigma-Aldrich (St. Louis, MO). ${ }^{13} \mathrm{C}-\mathrm{SMZ}$ was used as an internal standard (IS). A stock solution of $500 \mathrm{mg} \mathrm{L}^{-1}$ was prepared using acetonitrile (Panreac, Barcelona, Spain) and formic acid ( $50 \mu \mathrm{L})$ was added to improve the SMZ solubility.

SMZ was added into the lab-made sewage at concentration levels of 200 (phase I), 400 (phase II), 600 (phase III), and $800 \mathrm{ng} \mathrm{L}^{-1}$ (phase IV). An SMZ stock solution of $95 \mathrm{mg} \mathrm{L}^{-1}$ was used to spike SMZ in the lab-made sewage at each concentration according to the phase.
This solution was prepared weekly in water and kept in a refrigerator.

\subsection{Chemical analysis}

Chemical oxygen demand (COD), $\mathrm{pH}$, and alkalinity analysis were performed according to the Standard Methods for the Examination of Water and Wastewater [35]. These analyses were done at least three times a week to verify the state of the anaerobic reactor. Also, volatile acids were analyzed according to Adorno et al. [36].

\subsection{Degradation kinetic}

To evaluate reactor removal kinetics, an ideal plug-flow reactor was used $[37,38]$ which is isothermal, in a permanent regime, and pseudo-homogenous that resulted only in an apparent kinetic parameter, which embodies the intrinsic kinetics, convective, and diffusive mass transfer phenomena. Experimental data were adjusted to a first-order kinetic equation, using a residual concentration as demonstrated below [39]:

$$
C=C_{\text {res }}+\left(C_{o}-C_{\text {res }}\right) \cdot \mathrm{e}^{k^{\text {app }} \Theta}
$$

where $C$ is the concentration in the bulk liquid, $C_{o}$ is the concentration in the influent stream, and $\Theta$ is the hydraulic retention time (h). The parameter $k^{\text {app }}$ is the apparent first-order removal rate constant, while the residual concentration $\left(C_{\text {res }}\right)$ is the concentration value in the reactor when the reaction rate value was zero. The $C_{\text {res }}$ adopted was the LOQ of COD and SPE online-LC-MS/MS, $50 \mathrm{mg} \mathrm{L}^{-1}$ and $100 \mathrm{ng} \mathrm{L}^{-1}$, respectively. To obtain the removal kinetics, samples were collected at sampler 1 corresponding to HRT of $4.50 \mathrm{~h}$, sampler 2 HRT of $9.00 \mathrm{~h}$, sampler $3 \mathrm{HRT}$ of $13.45 \mathrm{~h}$, sampler 4 HRT of $17.95 \mathrm{~h}$, and sampler 5 HRT $24.00 \mathrm{~h}$.

To compare COD and SMZ removal constants, the Shapiro-Wilk test for normality was applied to verify whether the samples presented a normal distribution. Thereafter, analysis of variance (ANOVA) was used to evaluate if COD and SMZ removal constants were statistically significant.

\section{Results and discussion}

\subsection{SPE online-LC-MS/MS}

As demonstrated in the previous method, SPE online-LCMS/MS was suitable to pre-concentrate and extract SMZ [32]. Furthermore, it was possible to separate $S M Z$ and its internal standard $\left({ }^{13} \mathrm{C}-\mathrm{SMZ}\right)$ from interferences in the labmade sewage and bioreactor effluent. A chromatogram 

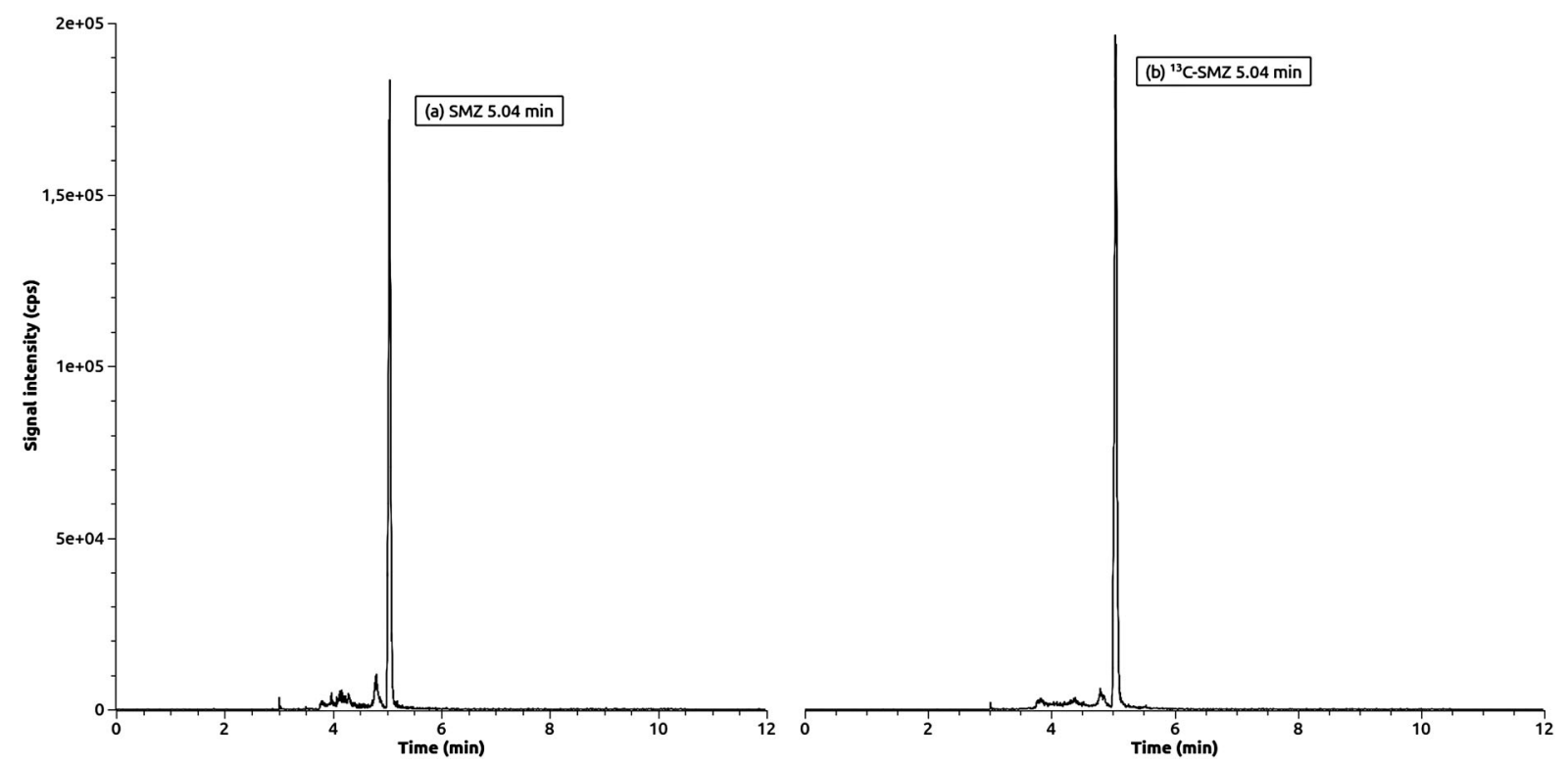

Figure 2. Extracted ion chromatogram of lab-made sewage spiked with SMZ (a) and ${ }^{13} \mathrm{C}-\mathrm{SMZ}$ (b) at 600 and $1000 \mathrm{ng} \mathrm{L^{-1 }}$, respectively.

of spiked lab-made sewage containing $600 \mathrm{ng} \mathrm{L}^{-1}$ of $\mathrm{SMZ}$ and $1000 \mathrm{ng} \mathrm{L}^{-1}$ of ${ }^{13} \mathrm{C}-\mathrm{SMZ}$ is shown in Figure 2.

LOQ for SMZ was $100 \mathrm{ng} \mathrm{L}^{-1}$. Linearity range for SMZ was $100-5400 \mathrm{ng} \mathrm{L}^{-1}$. Linearity did not present lack of fit and correlation coefficient was higher than 0.98. A weighted least-squares linear regression of $1 / x^{2}$ was applied only for the bioreactor effluent. Also, intra- and inter-day precision was lower than $6 \%$. Signal suppression was observed in a previous study of [32] for both matrices, the lab-made sewage and bioreactor effluent, therefore, ${ }^{13} \mathrm{C}-\mathrm{SMZ}$ was used as IS to minimize this effect. Calibration curves were constructed based on matrix-matching, one influent curve was developed on the lab-made sewage and other on the anaerobic bioreactor effluent without SMZ. These procedures were adopted to prevent lack of precision during the analysis applied in this study.

\subsection{COD removal}

The influent COD was $555.9 \pm 54.85 \mathrm{mg} \mathrm{O}_{2} \mathrm{~L}^{-1}$. The raw effluent COD was $58.89 \pm 22.72 \mathrm{mg} \mathrm{O}_{2} \mathrm{~L}^{-1}$, while the filtrated effluent $\mathrm{COD}$ was $34.38 \pm 12.19 \mathrm{mg} \mathrm{O}_{2} \mathrm{~L}^{-1}$. Thus, the ABFSB removal efficiency obtained for raw effluent was $89.26 \pm 4.022 \%$, and $91.01 \%$ for filtered effluent, resulting in significant COD removal. Figure 3 shows the COD data of influent and effluent throughout 38 weeks of operation.

From the beginning of ABFSB operation, until the 6th week, the bioreactor was in a stabilization process, indicating lower raw effluent removal efficiency. On the 8th week of operation, SMZ was added into the influent and no change in the COD removal efficiency was observed during phases I and II (27th week). However, on the 33rd week, SMZ was applied at a concentration of $600 \mathrm{ng} \mathrm{L}^{-1}$ and a slight decrease in COD removal efficiency was observed in the ABFSB. This outcome may have been initiated due to the increase in the SMZ concentration which can inhibit microorganisms. Nevertheless, once $800 \mathrm{ng} \mathrm{L}^{-1} \mathrm{SMZ}$ was added in the influent (36th week), it was apparent that there was no microorganism inhibition.

\subsection{SMZ removal efficiency}

Table 2 shows SMZ concentration levels monitored in the bioreactor influent and effluent during each operation phase.

SMZ removal efficiency remained constant at different concentrations imposed on the ABFSB bioreactor. However, there was a slight decrease in efficiency $(48.8 \pm 5.44 \%)$ in phase IV $\left(800 \mathrm{ng} \mathrm{L}^{-1}\right.$ of SMZ), which is not conclusive of microorganism inhibition.

Mitchell et al. [40] studied the influence of SMZ in the biogas production during the anaerobic digestion. SMZ was studied in a concentration range of $0.28-280 \mathrm{mg} \mathrm{L}^{-1}$ and anaerobic digestion was not negatively impacted. The same effect was observed by Cetecioglu et al. [41] for sulfamethoxazole, on concentration lower than 250 $\mathrm{mg} \mathrm{L}^{-1}$, which did not impact biogas production. The proposed study evaluated SMZ in two orders of magnitude lower than quoted studies, in $\mathrm{ng} \mathrm{L}^{-1}$ concentration level. This concentration range studied is found in wastewater such as domestic sewage. As expected, no microorganism inhibition occurred, mainly related to the low dosage, could not impair the anaerobic microbiota. 


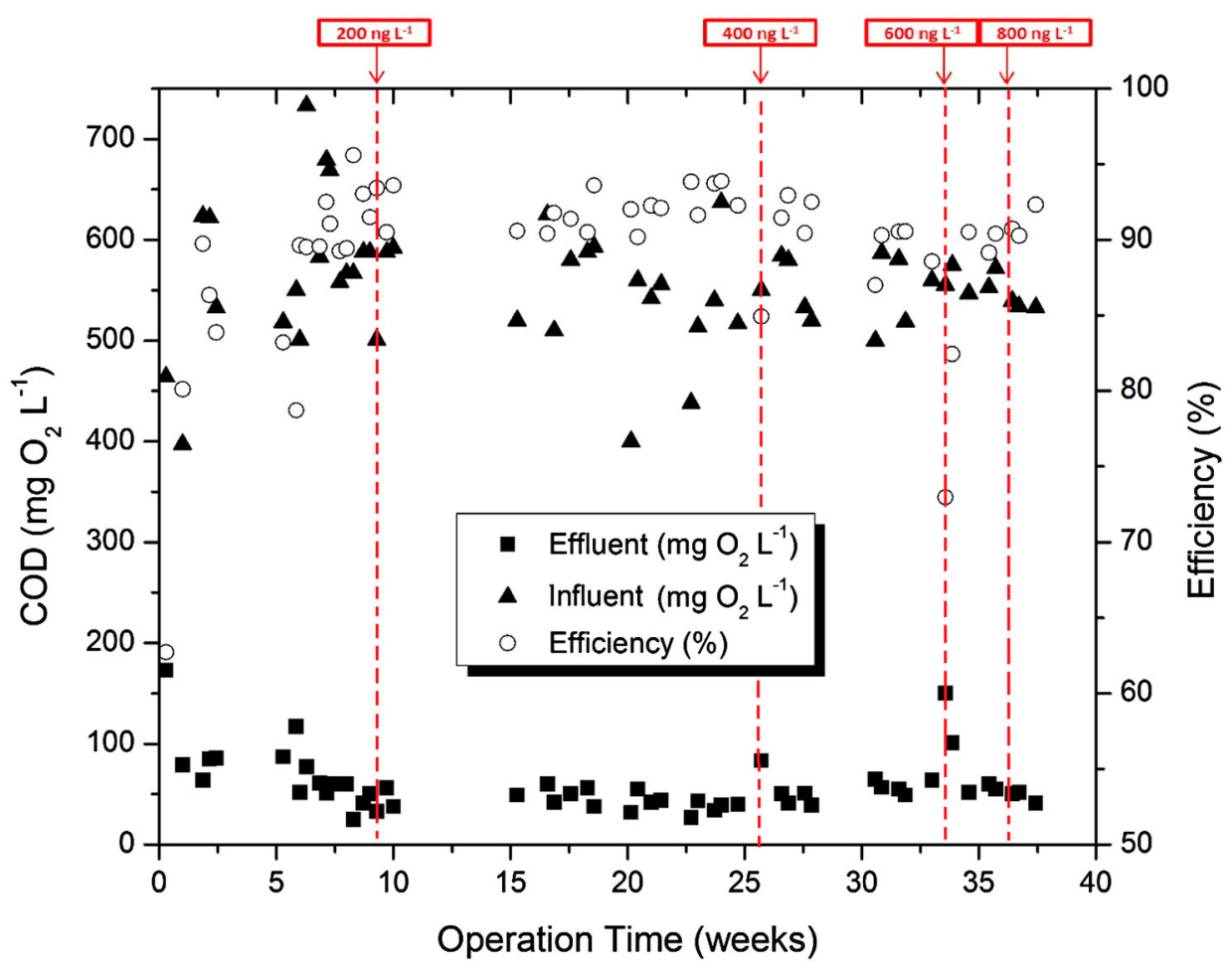

Figure 3. ABFSB COD removal efficiency.

Removal process can occur by adsorption, chemical hydrolysis, volatilization, and biodegradation mechanisms. Oliveira et al. [42] evaluated the removal of SMZ by chemical hydrolysis and volatization in batch reactors and found that these processes were negligible. These authors also evaluated studied SMZ adsorption on inactivated granular sludge and observed $45.8 \%$ of contribution. In this study, SMZ adsorption on foam strips was not evaluated, then the removal related refers to the sum of biodegradation and adsorption processes.

The ABFSB bioreactor was suitable to remove SMZ, since, sulfonamides are recalcitrant compounds and resistant to biodegradation through the wastewater treatment process, thereby not completely removed [43]. García-Galán et al. evaluated antibiotics removal by a conventional activated sludge (CAS) and advanced membrane bioreactor (MBR) from a wastewater treatment plant. The removal of SMZ using CAS treatment was only $22.3 \%$, while $49.1 \%$ was observed in the MBR. Behera et al. [44] observed poor removal of several

Table 2. SMZ concentration level and removal efficiency during bioreactor operation.

\begin{tabular}{lcccc}
\hline Parameters & $\left(200 \mathrm{ng} \mathrm{L}^{-1}\right)$ & $\left(400 \mathrm{ng} \mathrm{L}^{-1}\right)$ & $\left(600 \mathrm{ng} \mathrm{L}^{-1}\right)$ & $\left(800 \mathrm{ng} \mathrm{L}^{-1}\right)$ \\
\hline $\begin{array}{c}\text { Time/days of } \\
\text { operation }\end{array}$ & 105 & 45 & 19 & 10 \\
$\begin{array}{l}\text { Influent }\left(\mathrm{ng} \mathrm{L}^{-1}\right) \\
\text { Effluent }\left(\mathrm{ng} \mathrm{L}^{-1}\right)\end{array}$ & $242 \pm 83.7$ & $420 \pm 55.4$ & $650 \pm 26.4$ & $886 \pm 49.3$ \\
Efficiency (\%) & $52.8 \pm 12.5$ & $190 \pm 32.4$ & $297 \pm 32.4$ & $451 \pm 40.2$ \\
\hline
\end{tabular}

antibiotics present in wastewater treatment plants using different types of bioreactors such as aerobic, anaerobic, and anoxic. SMZ was poorly removed lower than $30 \%$. Chen et al. [45] studied a pilot-scale bioreactor using an anaerobic pool, aerobic biological filter, and oxidation pond. SMZ was poorly removed in the anaerobic pool, reaching only $27.6 \%$ of removal efficiency. In our study, in a lab-scale bioreactor, the removal efficiency varied from $55 \%$ to $48 \%$, superior to all previous studies here quoted. Oliveira et al. [42] studied batch

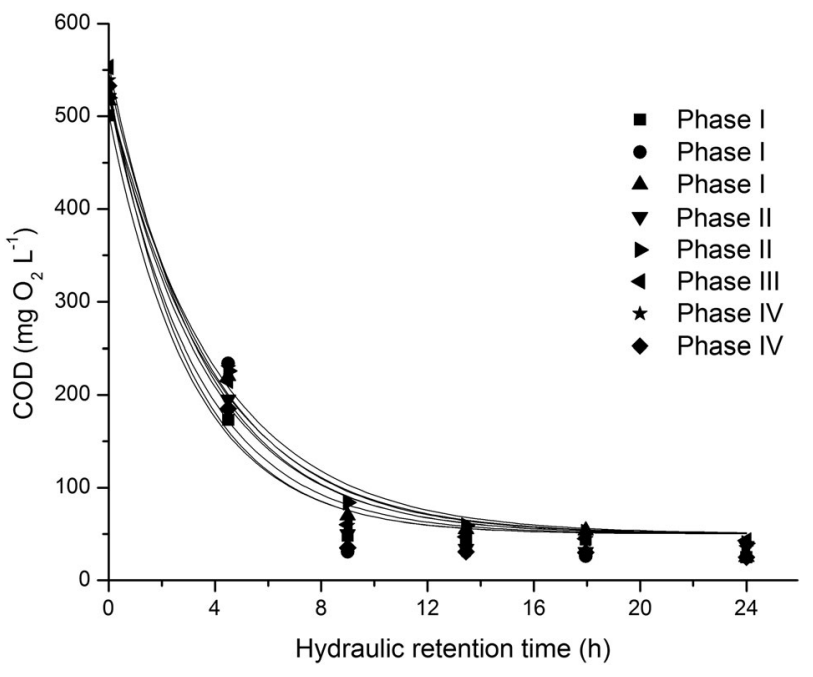

Figure 4. Organic matter removal kinetic profiles. 
Table 3. Apparent first-order kinetic constant $\left(k^{\text {app }}\right)$ for organic matter removal.

\begin{tabular}{lc}
\hline Bioreactor operation phase & $k^{\mathrm{app}}\left(\mathrm{h}^{-1}\right)$ \\
\hline Phase I & 0.320 \\
Phase I & 0.275 \\
Phase I & 0.256 \\
Phase I & 0.300 \\
Phase II & 0.243 \\
Phase III & 0.280 \\
Phase IV & 0.264 \\
Phase IV & 0.328
\end{tabular}

reactors using granular sludge to remove SMZ present in lab-made piggery wastewater and obtained a similar removal of $57 \%$ without the addition of co-substrate to the lab-made wastewater.

\subsection{Organic matter degradation kinetics}

In order to estimate the kinetic parameters, the ABFSB was considered as plug-flow, as proposed by Mockaitis et al. [25]. Moreover, Blanco et al. [46] performed hydrodynamic assay in this configuration and N-CSTR in series model was used to fit the experimental data. The number of ideal CSTRs in series was 400 for abiotic assay and 100 for microbial activity and biogas production. In both situations, the assays indicated that the plug-flow model can suitably represent the reactor.

Eight kinetic profiles (Figure 4) of the ABFSB were evaluated in the 10th week (phase I), 16th week (phase I), 25th week (phase I), 28th week (phase II), 32nd week (phase II), 36th week (phase III), 37th week (phase IV), and 38th week (phase IV). Samples were collected from four intermediate points and from the final effluent, with a HRT of 4.50, 9.00, 13.45, 17.95, and $24.00 \mathrm{~h}$.

The different kinetic profiles have an appropriate $R^{2}$, with a mean of $98.1 \pm 1.3 \%$, which resulted in a firstorder equation with residual. At the HRT of $9 \mathrm{~h}, \mathrm{COD}$ concentration decreased to values lower than LOQ which
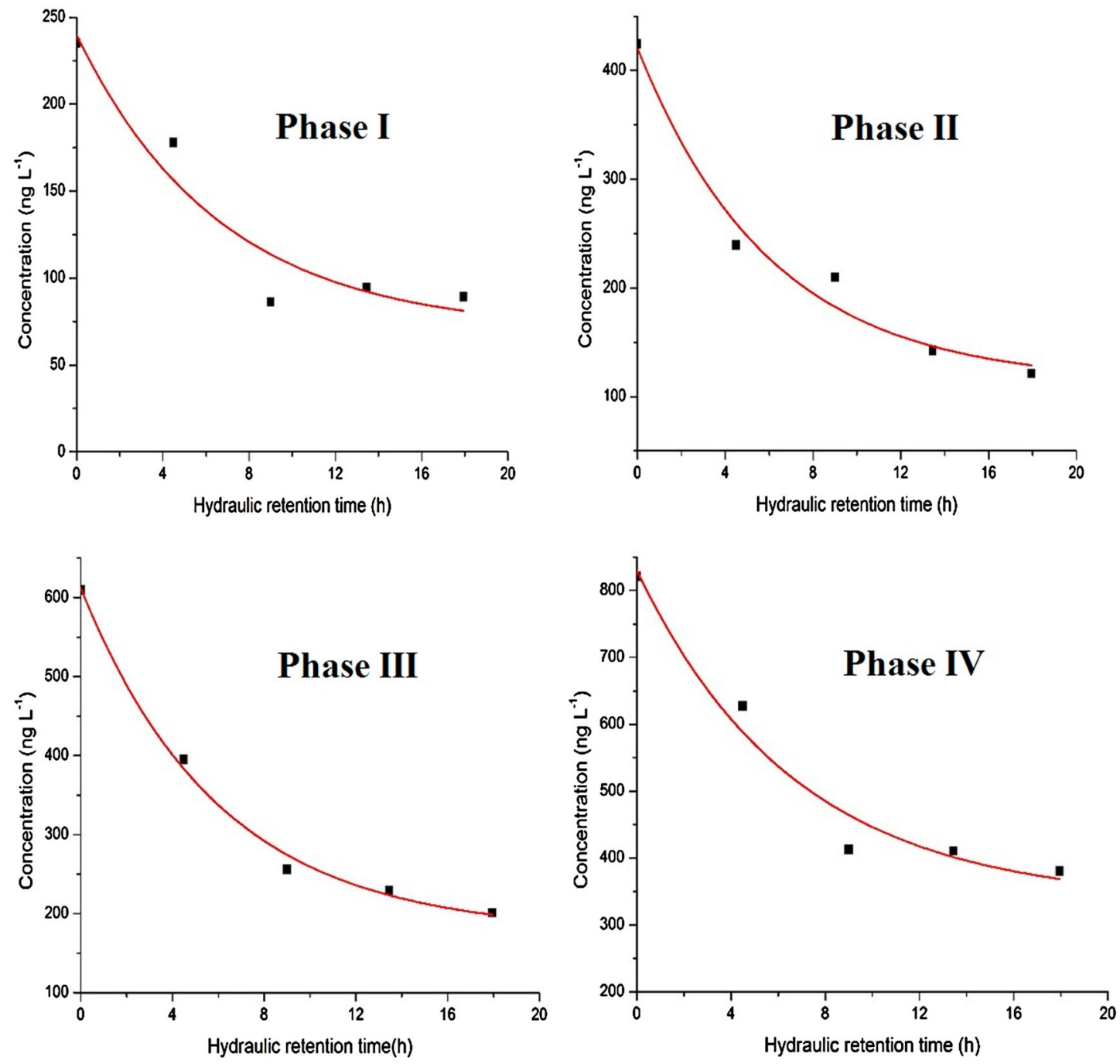

Figure 5. SMZ concentration behavior in the ABFSB profile. 
Table 4. Apparent first-order kinetic constant $\left(k^{S M Z}\right)$ for $S M Z$ removal.

\begin{tabular}{lc}
\hline SMZ concentration level $\left(\mathrm{ng} \mathrm{L}^{-1}\right)$ & $k^{\mathrm{SMZ}}\left(\mathrm{h}^{-1}\right)$ \\
\hline 200 & 0.150 \\
400 & 0.165 \\
600 & 0.166 \\
800 & 0.149 \\
\hline
\end{tabular}

suggests that a lower HRT time is necessary to remove the organic matter.

Table 3 shows the COD apparent first-order kinetics $\left(k^{\text {app}}\right)$ throughout the ABFSB as well as their respective kinetic equations.

The addition of SMZ at concentrations of 200 and 600 $\mathrm{ng} \mathrm{L}^{-1}$ did not significantly hinder the COD removal. However, there was a decrease in the COD removal rate in phase $\|$ (400 $\mathrm{ng} \mathrm{L}^{-1}$ of SMZ), $k^{\text {app }}$ of $0.243 \pm 0.0403 \mathrm{~h}^{-1}$. The last two kinetic profiles are related to phase IV (800 $\left.\mathrm{ng} \mathrm{L}^{-1} \mathrm{SMZ}\right)$. The decrease in the $k^{\text {app }}$ value was expected to repeat. However, this is unlikely to occur, as the $k^{\text {app }}$ remained the same in phases I and III, which demonstrates the non-inhibition of ABFSB microorganisms even at a concentration of $800 \mathrm{ng} \mathrm{L}^{-1}$. Furthermore, according to the Shapiro-Wilk test, the samples showed a normal distribution. The ANOVA test determined that the four phase values of $k^{\text {app }}$ are not statistically different. The average of $k^{\text {app }}$ was0.283 $\pm 0.0303 \mathrm{~h}^{-1}$.

\subsection{SMZ degradation kinetics}

The same procedure used to evaluate COD kinetics was applied for SMZ. Although the SMZ was analyzed using LC-MS/MS. Figure 5 shows SMZ removal according to HRT.

Table 4 shows the spatial profiles of SMZ kinetic removal $\left(k^{\mathrm{SMZ}}\right)$.

According to the Shapiro-Wilk test, the samples showed a normal distribution. The ANOVA test determined that the four $k^{\mathrm{SMZ}}$ values are not statistically different. The average of $k^{\mathrm{SMZ}}$ was $0.158 \pm 0.0093 \mathrm{~h}^{-1} \cdot k^{\mathrm{SMZ}}$ does not vary significantly, therefore, there was the occurrence of non-inhibition microorganisms. Also, SMZ is removed in the early stages of the ABFSB bioreactor, which indicates the possible application of lower HRT with no removal efficiency loss. Due to the low concentrations of SMZ in the reactor, the microbiological activity was not reduced and maintained stable, as observed in the kinetic profiles and also by the $k^{\text {app }}$ and $k^{\mathrm{SMZ}}$. Both constants can be compared due to the unchanged mass transfer resistance in each phase; therefore, the modifications are only due to the kinetics.

SMZ and COD degradation kinetics generated different apparent first-order kinetic constants. COD kinetic removal constants were higher than the values for SMZ kinetic constant, indicating faster COD removal than $S M Z$, this could be related to $S M Z$, recalcitrant compounds with a complex molecular structure. SMZ is removed by co-metabolism as observed by Oliveira et al. [42]. In this particular study, sucrose was added as an easily degradable exogenous COD source. Without sucrose, SMZ removal was 57\%; after adding sucrose, $\mathrm{SMZ}$ removal increased to $84 \%$. A similar effect was observed in our study. COD removal decreases drastically at the HRT of $9 \mathrm{~h}$, the same profile is observed for SMZ. COD present in the lab-made sewage achieved maximum removal at the same HRT of SMZ indicating co-metabolism.

\section{Conclusion}

In this study, the ABSFB has significant COD removal even at different concentration levels of $S M Z$ in labmade sewage, exhibiting high removal efficiency. Furthermore, SMZ has a substantial average removal of $52.4 \pm 2.60 \%$. COD and SMZ removal occurred according to a first-order kinetic model. Owing to a slight variation in SMZ and COD removal constant, the ABSFB exhibits the absence of a significant inhibition effect with an increase in the concentration level of SMZ. The $A B S F B$, therefore, can be considered a potential reactor to remove low concentrations of active pharmaceutical compounds in wastewater treatment plants with satisfactory efficiency even using HRTs of $9 \mathrm{~h}$, which is interesting for large-scale applications.

\section{Disclosure statement}

There is no conflict of interest by the authors.

\section{Funding}

Guilherme F. Romeiro thanks Fundação de Amparo à Pesquisa do Estado de São Paulo scholarship N. 14/10256-5. Paulo C. F. Lima Gomes thanks Fapesp scholarship N. 12/07153-4. Also, Marcelo Zaiat thanks Fapesp process N. 09/15984-0 and 09/53850-6 for the research grant and Paulo C. F. Lima Gomes thanks Conselho Nacional de Desenvolvimento Científico e Tecnológico process N. 475756/2013-4 for the research grant.

\section{ORCID}

Guilherme Flandoli Romeiro (D) http://orcid.org/0000-0002-45578514

Cristiane Arruda Oliveira (D) http://orcid.org/0000-0002-03054050

Inês N. Tomita (iD http://orcid.org/0000-0001-9587-6766

Alvaro Santos-Neto (i) http://orcid.org/0000-0003-1719-8458 
Marcelo Zaiat (D) http://orcid.org/0000-0001-7336-9093

Paulo Clairmont F. Lima Gomes (D) http://orcid.org/0000-00024837-6352

\section{References}

[1] Carvalho IT, Santos L. Antibiotics in the aquatic environments: a review of the European scenario. Environ Int. 2016;94:736-757.

[2] Sodré FF, Locatelli MAF, Jardim WF. Occurrence of emerging contaminants in Brazilian drinking waters: a sewage-to-tap issue. Water Air and Pollut. 2009;206 (1):57-67.

[3] Gracia-Lor E, Sancho JV, Serrano R, et al. Occurrence and removal of pharmaceuticals in wastewater treatment plants at the Spanish Mediterranean area of Valencia. Chemosphere. 2012;87(5):453-462.

[4] Kümmerer K. Antibiotics in the aquatic environment - a review - part I. Chemosphere. 2009;75(4):417-434.

[5] Batt AL, Snow DD, Aga DS. Occurrence of sulfonamide antimicrobials in private water wells in Washington County, Idaho, USA. Chemosphere. 2006;64(11):1963-1971.

[6] Accinelli C, Hashim M, Epifani R, et al. Effects of the antimicrobial agent sulfamethazine on metolachlor persistence and sorption in soil. Chemosphere. 2006;63(9):1539-1545.

[7] Li W, Shi Y, Gao L, et al. Occurrence, distribution and potential affecting factors of antibiotics in sewage sludge of wastewater treatment plants in China. Sci Total Environ. 2013;445-446:306-313.

[8] García-Galán MJ, Díaz-Cruz MS, Barceló D. Kinetic studies and characterization of photolytic products of sulfamethazine, sulfapyridine and their acetylated metabolites in water under simulated solar irradiation. Water Res. 2012;46(3):711-722.

[9] Le-Minh N, Stuetz RM, Khan SJ. Determination of six sulfonamide antibiotics, two metabolites and trimethoprim in wastewater by isotope dilution liquid chromatography/ tandem mass spectrometry. Talanta. 2012;89:407-416.

[10] Focazio MJ, Kolpin DW, Barnes KK, et al. A national reconnaissance for pharmaceuticals and other organic wastewater contaminants in the United States - II - untreated drinking water sources. Sci Total Environ. 2008;402 (2):201-216.

[11] Wishart DS, Feunang YD, Guo AC, et al. DrugBank 5.0: a major update to the DrugBank database for 2018. Nucleic Acids Res. 2017; Nov 8. doi: 10.1093/nar/gkx1037.

[12] Gao Y, Gao N, Deng Y, et al. Factors affecting sonolytic degradation of sulfamethazine in water. Ultrason Sonochem. 2013;20(6):1401-1407.

[13] Dolar D, Gros M, Rodriguez-Mozaz S, et al. Removal of emerging contaminants from municipal wastewater with an integrated membrane system, MBR-RO. J Hazard Mater. 2012;239:64-69.

[14] Zhang Y, Marrs CF, Simon C, et al. Wastewater treatment contributes to selective increase of antibiotic resistance among Acinetobacter spp. Sci Total Environ. 2009;407 (12):3702-3706.

[15] Abraham WR, Macedo AJ, Gomes LH, et al. Occurrence and resistance of pathogenic bacteria along the Tietê river downstream of São Paulo in Brazil. Clean Soil Air Water. 2007;35(4):339-347.
[16] O'Neill J (Chair). The review on antimicrobial resistance; December 2014.

[17] IBGE. Instituto Brasileiro de Geografia e Estatística - pesquisa nacional de saneamneto básico, Rio de Janeiro; 2010.

[18] Zorita S, Martensson L, Mathiasson L. Occurrence and removal of pharmaceuticals in a municipal sewage treatment system in the south of Sweden. Sci Total Environ. 2009;407(8):2760-2770.

[19] Jones O, Voulvoulis N, Lester J. Aquatic environmental assessment of the top 25 english prescription pharmaceuticals. Water Res. 2002;36(20):5013-5022.

[20] Brandt EMF, de Queiroz FB, Afonso RJCF, et al. Behaviour of pharmaceuticals and endocrine disrupting chemicals in simplified sewage treatment systems. J Environ Manag. 2013;128:718-726.

[21] Cruz-Morató C, Ferrando-Climent L, Rodriguez-Mozaz S, et al. Degradation of pharmaceuticals in non-sterile urban wastewater by Trametes versicolor in a fluidized bed bioreactor. Water Res.. 2013;47(14):5200-5210.

[22] Chernicharo CAL. Anaerobic Reactors. 1st ed. London: IWA publishing; 2007.

[23] Fuess LT, de Araújo Júnior MM, Garcia $M L$, et al. Designing full-scale biodigestion plants for the treatment of vinasse in sugarcane biorefineries: How phase separation and alkalinization impact biogas and electricity production costs?. Chem Eng Res Des. 2017;119:209-220.

[24] Chatila S, Amparo MR, Carvalho LS, et al. Sulfamethoxazole and ciprofloxacin removal using a horizontal-flow anaerobic immobilized biomass reactor. Environ Technol. 2015;37(7):847-853.

[25] Mockaitis G, Pantoja JLR, Rodrigues JAD, et al. Continuous anaerobic bioreactor with a fixed-structure bed (ABFSB) for wastewater treatment with low solids and low applied organic loading content. Bioprocess Biosyst Eng. 2014;37(7):1361-1368.

[26] Camiloti PR, Mockaitis G, Domingues Rodrigues JA, et al. Innovative anaerobic bioreactor with fixed-structured bed (ABFSB) for simultaneous sulfate reduction and organic matter removal. J Chem Technol Biotechnol. 2014;89(7):1044-1050.

[27] Zaiat M, Cabral AKA, Foresti E. Reator Anaeróbio Horizontal de Leito Fixo Para Tratamento de Águas Residuárias: Concepção e Avaliação Preliminar de Desempenho. Rev Bras Eng Química. 1994;11(2):33-42.

[28] Chunhui Z, Liangliang W, Gao Xiangyu HX. Antibiotics in WWTP discharge into the Chaobai River, Beijing. Arch Environ Prot. 2016;42:48-57.

[29] Queiroz FB, Brandt EMF, Aquino SF, et al. Occurrence of pharmaceuticals and endocrine disruptors in raw sewage and their behavior in UASB reactors operated at different hydraulic retention times. Water Science Technol. 2012;66(12):2562-2569.

[30] Farré $M$, Kantiani $L$, Petrovic $M$, et al. Achievements and future trends in the analysis of emerging organic contaminants in environmental samples by mass spectrometry and bioanalytical techniques. J Chromatogr A. 2012;1259:86-99.

[31] Richardson SD. Environmental mass spectrometry: emerging contaminants and current issues. Anal Chem. 2008;80(12):4373-4402. 
[32] Lima Gomes PCF, Tomita IN, Santos-Neto ÁJ, et al. Rapid determination of 12 antibiotics and caffeine in sewage and bioreactor effluent by online column-switching liquid chromatography/tandem mass spectrometry. Anal Bioanal Chem. 2015;407 (29):8787-8801.

[33] Thompson M, Elisson SLR, Wood R. Harmonized guidelines for single-laboratory validation of methods of analysis. Pure Appl Chem. 2002;74(5):835-855.

[34] Food Administration Department. Analytical procedures and methods validation for drugs and biologics. Guidance for industry. Pharmaceutical Quality/CMC, vol. 1; 2015, 1-18.

[35] Clesceri L, Greenberg A, Eaton A. Standard methods for the examination of water and wastewater. 22th ed. APHA American Public Health Association; 2005.

[36] Adorno MAT, Hirasawa JS, Varesche MBA. Development and validation of two methods to quantify volatile acids (C2-C6) by GC/FID: Headspace (Automatic and Manual) and Liquid-Liquid Extraction (LLE). Am J Anal Chem. 2014;5:406-414.

[37] Lima DMF, Zaiat M. The influence of the degree of back-mixing on hydrogen production in an anaerobic fixed-bed reactor. Int J Hydrog Energy. 2012;37 (12):9630-9635.

[38] Levenspiel O. Chemical reaction engineering: an introduction to the design of chemical reactors. 3rd ed. New York (NY): Wiley; 1999.

[39] Camargo E, Ratusznei S, Rodrigues J, et al. Treatment of low-strength wastewater using immobilized biomass in a sequencing batch external loop reactor: influence of the medium superficial velocity on the stability and performance. Braz J Chem Eng. 2002; 19:267-275.

[40] Mitchell SM, Ullman JL, Teel AL, et al. The effects of the antibiotics ampicillin, florfenicol, sulfamethazine, and tylosin on biogas production and their degradation efficiency during anaerobic digestion. Bioresour Technol. 2013;149:244-252.

[41] Cetecioglu Z, Ince B, Orhon D, et al. Acute inhibitory impact of antimicrobials on acetoclastic methanogenic activity. Bioresour Technol. 2012;114:109-116.

[42] Oliveira GHD, Santos-Neto AJ, Zaiat M. Evaluation of sulfamethazine sorption and biodegradation by anaerobic granular sludge using batch experiments. Bioprocess Biosyst Eng. 2016;39(1):115-124.

[43] Batt AL, Kim S, Aga DS. Comparison of the occurrence of antibiotics in four full-scale wastewater treatment plants with varying designs and operations. Chemosphere. 2007;68(3):428-435.

[44] Behera SK, Kim HW, Oh JE, et al. Occurrence and removal of antibiotics, hormones and several other pharmaceuticals in wastewater treatment plants of the largest industrial city of Korea. Sci Total Environ. 2011;409(20):43514360.

[45] Chen J, Liu YS, Zhang JN, et al. Removal of antibiotics from piggery wastewater by biological aerated filter system: treatment efficiency and biodegradation kinetics. Bioresour Technol. 2017;238:70-77.

[46] Blanco VMC, Fuess LT, Zaiat M. Calcium dosing for the simultaneous control of biomass retention and the enhancement of fermentative biohydrogen production in an innovative fixed-film bioreactor. Int J Hydrog Energy. 2017;42(17):12181-12196. 